\title{
Liability for Past Environmental Contamination and Privatization
}

\author{
By: Dietrich Earnhart
}

Working Paper Number 302

March 2000 


\title{
Liability for Past Environmental Contamination and Privatization
}

\author{
Dietrich Earnhart \\ University of Kansas
}

\author{
Department of Economics \\ University of Kansas \\ 213 Summerfield Hall \\ Lawrence, KS 66045 \\ (785) 864-2866 \\ Earnhart@ukans.edu
}

March 22, 2000

\begin{abstract}
This paper examines the role of liability for past environmental contamination in the privatization processes of Central and Eastern Europe. The theoretical section establishes a link between a risk-averse investor's amount of information regarding the extent of past environmental contamination (and its cleanup costs) and the investor's willingness to pay for a particular enterprise, i.e., bid. As the investor obtains a more precise estimate of the uncertain cleanup costs, the investor faces less risk; therefore, the investor's risk premium falls and the investor's bid rises. This link generates four hypotheses regarding a privatization agency's responses to the investor's knowledge of cleanup costs. The empirical section of this paper proposes to test these hypotheses with forthcoming analysis using data from the Czech Republic.
\end{abstract}

I wish to thank the following people for their assistance, advise, and support: Don Lien, Tom Weiss, Rick Lotspeich, Jiøina Jilková, Zdenek Svoboda, and James Boyd. I also thank the feedback from participants at the 1999 Association for Comparative Economic Studies (ACES) meetings and the 1999 American Law and Economics Association (ALEA) meetings. Needless to say, all errors remain my responsibility. 


\section{Non-technical Summary}

Under the former communist regimes in the Central and Eastern Europe, economic activities severely degraded the region's environment. Various types of economic facilities severely contaminated the air, water, and soil surrounding their sites by emitting and dumping numerous pollutants. Therefore, most commercial and industrial sites in Central and Eastern Europe are presently contaminated, if not severely so. Such contamination was widely reported shortly after the communist regimes fell.

Strangely enough, privatization agencies in Central and Eastern Europe responsible for the transfer of ownership over these facilities were taken aback by investors' concerns over the liability for any remediation of this widespread and severe contamination. Foreign investors were especially concerned by the potential liability for two reasons. First, they correctly believed that governments wished to tap the foreign investors" "deep pockets" for financing the cleanup of this large-scale degradation. Second, foreign investors recalled their previous experiences in Western industrialized economies over retroactive liability for environmental contamination, such as Superfund liability for hazardous waste contamination in the United States.

After acknowledging the investors' concerns, privatization agencies responded with policies to reallocate liability for the cleanup costs. First, they responded with price reduction policies, but only on an ad hoc basis. Later, privatization agencies in some countries developed more systematic and thoughtful policies, such as indemnification of private liability using reimbursement schemes. Moreover, governments decided to gather more complete information on cleanup decisions before rushing into compensation schemes.

These government policy decisions were designed to facilitate the privatization process and presumably to increase the sales revenues generated by direct sales, auctions, and other privatization methods. Investors facing liability for cleanup costs would be expected to discount their bid for a contaminated enterprise commensurate with the extent of required cleanup. Of course, investors did not understand the extent of contamination and therefore cleanup costs with perfect certainty. Instead, most investors understood the level of cleanup costs with great uncertainty. As long as investors are risk-averse, the existence of uncertainty (i.e., risk), will prompt them to seek a risk premium to compensate them for bearing this risk. This risk premium drives down the investor's bid for a contaminated enterprise. Therefore, an inverse relationship exists between the precision of the investor's estimation of cleanup costs (i.e., information about cleanup costs) and the investor's bid. Given this connection, privatization agencies should be expected to offer greater compensation to investors in the form of price discounts when the investor's estimation of cleanup costs is imprecise. This logic generates the first of four testable hypotheses: when the state offers only price discounts without indemnification, the degree of price discount is inversely related to the amount of information known by the investor.

This logic extends to the policy of offering compensation in the form of indemnification from private liability (e.g., reimbursement for cleanup costs). Of course, in this case the state bears the indemnified cleanup costs. In addition, the state faces other expenses associated with indemnification. These expenses may include administrative expenses for operating any reimbursement program. They also may 
include costs claimed as past environmental contamination by the investor yet generated after privatization. This possibility is quite feasible since it may be very difficult, if not impossible, to separate past and current environmental contamination. Less obviously, indemnification may generate higher future cleanup costs by undermining the polluter pays principle and degrading deterrence of future contaminating activities.

Given these additional indemnification expenses, the inverse relationship between the investor's amount of information and his/her bid drives the choice between zero and full indemnification and the choice of partial indemnification. When the state is deciding between zero and full indemnification, it is more likely to offer full indemnification as the investor's information degrades because the risk premium is more likely to exceed the administrative expenses associated with indemnification. The opposite result follows as the investor's information improves: the state is more likely to offer zero indemnification. These predictions represent two additional testable hypotheses. Finally, consider the case where the state is selecting any level of indemnification (including zero, partial, and full). In this scenario, indemnification lowers the investor's risk premium similar to information because indemnification limits the scope of the investor's liability. Yet, these two factors are assumed to be complements; that is, indemnification reduces the investor's risk more when he/she possess poor information about cleanup costs. Given this relationship, the state raises the level of indemnification as the investor's information degrades because indemnification becomes a stronger tool for lowering the investor's risk premium. This prediction represents the final testable hypothesis.

The empirical section of this paper proposes to test all the noted hypotheses with forthcoming analysis of the privatization process in the Czech Republic.

Acknowledgements: I wish to thank the following people for their assistance, advise, and support: Don Lien, Tom Weiss, Rick Lotspeich, Ji_ina Jilková, Zdenek Svoboda, and James Boyd. I also thank the feedback from participants at the 1999 Association for Comparative Economic Studies (ACES) meetings and the 1999 American Law and Economics Association (ALEA) meetings. Finally, I acknowledge the financial assistance of the New Faculty General Research Fund Award and the International Research Award from the University of Kansas.

\section{Relevant JEL Classification Numbers and Keywords: D80, K32, Q24, Q25 \\ liability, privatization, risk, environmental contamination}




\section{Introduction}

Under the former communist regimes in the Central and Eastern Europe, economic activities severely degraded the environment throughout the region. Various types of economic facilities industry, agriculture, military operations — severely contaminated the air, water, and soil surrounding their sites by emitting and dumping numerous pollutants. Therefore, most commercial and industrial sites in Central and Eastern Europe are presently contaminated, if not severely so. Such contamination was widely reported shortly after the communist regimes fell.

Strangely enough, privatization agencies in Central and Eastern Europe responsible for the transfer of ownership over these facilities were taken aback by investors' concerns over the liability for any remediation of this widespread and severe contamination. Foreign investors were especially concerned by the potential liability for two reasons. First, they correctly believed that governments wished to tap the foreign investors' "deep pockets" for financing the cleanup of this large-scale degradation (Goldenman, 1995). Second, foreign investors recalled their previous experiences in Western industrialized economies over retroactive liability for environmental contamination, such as Superfund liability for hazardous waste contamination in the United States (World Bank/OECD, 1992).

After acknowledging the investors' concerns, privatization agencies responded with policies to reallocate liability for the cleanup costs. First, they responded with price reduction policies, but only on an ad hoc basis. Later, privatization agencies in some countries developed more systematic and thoughtful policies, such as indemnification of private liability using reimbursement schemes (Kružíková and Drobnik, 1993). Moreover, governments decided to gather more complete information on cleanup decisions before rushing into compensation schemes. 
These government policy decisions were designed to facilitate the privatization process and presumably to increase the sales revenues generated by direct sales, auctions, and other privatization methods. Investors facing liability for cleanup costs would be expected to discount their bid for a contaminated enterprise commensurate with the extent of required cleanup. Of course, investors did not understand the extent of contamination and therefore cleanup costs with perfect certainty. Instead, most investors understood the level of cleanup costs with great uncertainty. As long as investors are risk-averse, the existence of uncertainty (i.e., risk), will prompt them to seek a risk premium to compensate them for bearing this risk. This risk premium drives down the investor's bid for a contaminated enterprise. Therefore, an inverse relationship exists between the precision of the investor's estimation of cleanup costs and the investor's bid. Given this connection, privatization agencies should be expected to offer greater compensation to investors, in the form of price discounts and indemnification from private liability (e.g., reimbursement for cleanup costs). From this connection, the theoretical section of the paper generates four hypotheses, which the empirical section proposes to test with forthcoming analysis of the privatization process in the Czech Republic.

\section{Environmental Liabilities}

\subsection{Details}

Privatization involves the transfer of ownership and control over assets from the state to the private sector. In Central and Eastern Europe, as in other industrialized countries, generally this process transfers all assets and liabilities to the new owner, unless the two contracting parties provide other arrangements, a rule called successor liability (Goldenman, 1995). Although most countries do not explicitly specify environmental liabilities in their laws, some countries, such as the Czech Republic, have explicitly stated this policy. For clarification, environmental liabilities fall into two 
broad categories: (1) contamination caused by current operations and (2) contamination stemming from past operations (i.e., preceding privatization). This analysis focuses exclusively on the second type of liability, commonly called past environmental damage (PED). ${ }^{1}$ This type of environmental contamination divides into four categories (Goldenman, 1995):

(1) on-site environmental contamination (e.g., soil contamination),

(2) off-site environmental contamination (e.g., groundwater aquifer contamination),

(3) injuries and illnesses suffered by employees of a facility, and

(4) damages to third parties (e.g., health problems born by neighboring residents).

The responsibility for any or all of these components of past environmental damage may be transferred to the new owner of a property (i.e., investor) as a liability. In other words, the investor must pay for the cleanup of this environmental contamination and/or compensate injured workers and damaged third parties.

Potential investors in state-owned enterprises in Central and Eastern Europe obviously did not wish to bear the burden of these liabilities. In a study of 1,000 large North American and West European firms, half of those who evaluated sites in Central and Eastern Europe rejected them partially on environmental grounds (The Economist, 1993). According to a World Bank/OECD survey of potential investors, liability for past environmental contamination ranked as the most important environmental concern (World Bank/OECD, 1992).

In response to these concerns, government agencies in Central and Eastern Europe have implemented alternative mechanisms of allocating liability for past environmental contamination. One mechanism offers a price reduction to the new owner. Presumably, this discount is commensurate

${ }^{1}$ See Boyd (1996) for an excellent analysis of how these two types of liabilities may be connected. 
with the anticipated cleanup costs. With another mechanism, the state indemnifies the private owner for all or part of the cleanup costs related to past environmental contamination, given certain restrictions, such as future compliance with environmental regulations. In this case, the state bears all or some of the cleanup costs. Regardless of the level of indemnification, the government may choose to perform the remediation itself or simply reimburse the investor for its cleanup costs. With a third mechanism, the state sets aside a portion of the sales revenues generated by a specific enterprise and earmarks these funds for reimbursement of cleanup costs born by the new owner. These arrangements are generally called escrow accounts.

\subsection{Theoretical Representation}

In all cases except full indemnification, the investor is left to face an uncertain liability. This uncertainty then prompts a risk-averse investor to alter its bid for any enterprise suspected of contamination. A risk-neutral investor reduces its bid by the expected liability costs. However, a risk-averse investor reduces its bid by this amount plus a risk premium. ${ }^{2}$ In order to attract investors, privatization agencies presumably must respond to this risk-averse behavior, regardless of the chosen re-allocation mechanism or compensation scheme.

The following three sections model formally this effect of risk-aversion on an investor's bid in the face of uncertain cleanup costs. The first of these sections displays how a risk-averse investor decreases its willingness-to-pay for an enterprise or increases its desire for compensation when facing uncertainty by including a risk premium in its bid. More important, this section highlights the importance of investor information about uncertain liability costs. As an investor gains greater information on these uncertain costs (i.e., as his/her cost estimate becomes more precise), the risk

\footnotetext{
2 Boyd (1994, p. 41) notes this type of investor behavior.
} 
associated with this liability declines. Consequently, a better informed investor requires less compensation because it involves a smaller risk premium. Since all liability mechanisms, except full indemnification, involve this uncertainty and thus generate a risk premium, choices over these mechanisms made by government agencies should reflect this relationship between information and the level of risk premium.

The following three sections develop three models to capture the choice of liability reallocation mechanism and the parameters of each mechanism. The first model concerns the case of complete uncertainty regarding liability costs, where the state imposes all liability on the private investor yet compensates the investor with a price reduction. The second model considers the dichotomy between complete uncertainty and complete certainty, where the state chooses between imposing full liability on the private investor and fully indemnifying the investor. The third model generalizes the first two models by adding the possibility for the state to offer partial indemnification. From these three models, theory generates four hypotheses, which forthcoming empirical analysis will test.

\section{Complete Uncertainty and Price Reduction}

Imagine that a risk-averse investor wishes to purchase a currently state-owned enterprise.

Prior to this potential purchase, the investor has an initial level of wealth, W:

$\mathrm{W}=$ initial level of investor wealth.

Disregarding any possible environmental liabilities, the investor knows with certainty the underlying value of the enterprise, based on the present value of the future profit stream, denoted $\mathrm{N}$,

$\mathrm{N}=$ present value of the enterprise's future profit stream.

The investor correctly believes that it is responsible for all liabilities associated with the enterprise, 
including environmental liabilities. However, the investor only imperfectly understands the extent of contamination at the facility and thus imperfectly observes the present value of the cleanup costs, denoted as $\mathrm{C}$,

$$
\mathrm{C}=\text { level of cleanup costs. }
$$

Instead, the investor knows only the distribution of these costs. More important, the subjective distribution depends on the amount of information about cleanup costs known by the investor. Define I as the metric that captures the amount of information:

$\mathrm{I}=$ metric for information about cleanup costs known by the investor,

so that I increases as information improves. Given this definition, costs are randomly distributed according to the probability distribution function $\mathrm{f}(\mathrm{C} \mid \mathrm{I})$ along the following interval:

$$
\mathrm{C} \in\left[\mathrm{C}_{\min }, \mathrm{C}_{\max }\right] .
$$

As the information metric increases, probability mass shifts towards the mean or expected value of the distribution, $\hat{\mathrm{C}}$,

$$
\hat{\mathrm{C}}=\text { mean or expected level of cleanup costs, }
$$

as shown in Figure 1. It is assumed that information has an unbiased effect on the investor's expected value of cleanup costs; i.e., $\hat{C}$ is independent of I. Information instead sharpens the precision of the investor's calculation of cleanup costs. Put differently, increased information reduces the uncertainty of cleanup costs. In mathematical terms, a distribution involving greater information, $\mathrm{f}\left(\mathrm{C} \mid \mathrm{I}^{\prime}\right)$, secondorder stochastically dominates a distribution involving less information, $f\left(C \mid I^{\prime \prime}\right)$, where $I^{\prime}>$ I"(Rothschild and Stiglitz, 1970; Rothschild and Stiglitz, 1971). In other words, $f\left(C \mid I^{\prime \prime}\right)$ represents 
a mean-preserving spread of $\mathrm{f}\left(\mathrm{C} \mid \mathrm{I}^{\prime}\right) .^{3}$

The investor values its wealth according to a strictly concave von Neumann-Morgenstern utility function, $\mathrm{U}(\bullet)$,

$\mathrm{U}(\bullet)$ = investor's utility function.

Prior to the potential purchase, the investor enjoys a reservation utility level, $\overline{\mathrm{U}}$,

$$
\overline{\mathrm{U}}=\mathrm{U}(\mathrm{W})=\text { reservation utility level. }
$$

To purchase the enterprise, the investor is willing to pay a maximum price of $\mathrm{P}$,

$$
\mathrm{P}=\text { maximum willingness to pay for enterprise, }
$$

which is defined more completely below. ${ }^{4}$ After the purchase, the investor has a net wealth, Y,

$$
\mathrm{Y}=\mathrm{W}+\mathrm{N}-\mathrm{C}-\mathrm{P}=\text { net wealth after purchase. }
$$

The investor is assumed to maximize its expected utility from the purchase, EU,

$$
E U(Y \mid I)=\int_{C} U(Y) f(C \mid I) d C=\text { expected utility from the purchase of the enterprise. }
$$

Next consider the role of the privatization agency. It seeks to sell the enterprise to the investor. In this effort, it seeks to maximize its own-country welfare, represented by net revenues from the sale of the enterprise. The investor's underlying valuation of the enterprise and the subjective distribution of cleanup costs is common knowledge. In addition, the agency knows the investor's utility function. In this case, the agency can extract all the rents from the investor by forcing the investor to pay a price so high that the investor only enjoys an expected utility exactly

${ }^{3}$ Bluffstone and Panayotou (1998) also examine the effect of information about cleanup costs on an investor's bidding for a state-owned enterprise.

${ }^{4}$ Thomas (1994) considers the case of many risk-neutral investors wishing to purchase a state-owned enterprise in an auction setting. In this setting, heterogenous information about the net value of the enterprise causes the winning bid to fall below the expected value of the enterprise. Nevertheless, each investor observes its unique level of net value with certainty, unlike the formulation of this paper. 
equal to its reservation utility:

$$
\mathrm{EU}(\mathrm{W}+\mathrm{N}-\mathrm{C}-\mathrm{P})=\int_{\mathrm{C}} \mathrm{U}(\mathrm{W}+\mathrm{N}-\mathrm{C}-\mathrm{P}) \mathrm{f}(\mathrm{C} \mid \mathrm{I}) \mathrm{dC}=\overline{\mathrm{U}} .
$$

This equality constraint defines $\mathrm{P}$, the investor's maximum willingness to pay for the enterprise. ${ }^{5}$ Note that expected utility cannot fall below $\overline{\mathrm{U}}$, otherwise the investor will not purchase the enterprise.

To capture the investor's behavior under uncertainty, the certainty equivalent of purchasing the enterprise with its uncertain cleanup costs is structured in the following way:

$$
\mathrm{U}(\mathrm{W}+\mathrm{N}-[\hat{\mathrm{C}}+ð(\mathrm{I})]-\mathrm{P} \mid \mathrm{I})=\mathrm{EU}(\mathrm{W}+\mathrm{N}-\mathrm{C}-\mathrm{P} \mid \mathrm{I}),
$$

where information, I, is fixed at a certain level. In other words, the investor is indifferent between accepting the outcome $\mathrm{W}+\mathrm{N}-[\hat{\mathrm{C}}+ð(\mathrm{I})]-\mathrm{P}$ with certainty and the outcome $\mathrm{W}+\mathrm{N}-\mathrm{C}-\mathrm{P}$ with uncertainty. The variable ð(I) is positive, since the investor is risk-averse, and depends on I, since EU depends on I. It also represents the risk premium associated with the uncertain purchase,

$$
ð(I)=\text { risk premium associated with uncertain purchase. }
$$

The risk premium is the difference between the expected level of net wealth and the certainty equivalent of the uncertain purchase:

$$
ð(\mathrm{I})=\mathrm{E}(\mathrm{W}+\mathrm{N}-\mathrm{C}-\mathrm{P} \mid \mathrm{I})-\{\mathrm{W}+\mathrm{N}-[\hat{\mathrm{C}}+ð(\mathrm{I})]-\mathrm{P}\}=(\mathrm{W}+\mathrm{N}-\hat{\mathrm{C}}-\mathrm{P})-\{\mathrm{W}+\mathrm{N}-[\hat{\mathrm{C}}+ð(\mathrm{I})]-\mathrm{P}\},
$$

for a given level of I.

Now consider the effect of cleanup costs and uncertainty on the investor's bidding behavior. When no cleanup costs are born or the distribution collapses all its probability mass at $\mathrm{C}=0$, the investor's bid equals the underlying value of the enterprise: $\mathrm{P}=\mathrm{N}$. When cleanup costs are positive but certain at their mean, $\hat{\mathrm{C}}$, the investor sets its bid at $\mathrm{P}=\mathrm{N}-\hat{\mathrm{C}}$. When cleanup costs become

${ }^{5}$ This assumption is not critical to the final result. Instead, the final result demands only that the final price paid depends positively on the investor's maximum price (i.e., willingness-to-pay). 
uncertain, use of the certainty equivalent identifies the investor's bid in the following way:

$$
\mathrm{U}(\mathrm{W})=\overline{\mathrm{U}}=\mathrm{EU}(\mathrm{W}+\mathrm{N}-\mathrm{C}-\mathrm{P} \mid \mathrm{I})=\mathrm{U}(\mathrm{W}+\mathrm{N}-[\hat{\mathrm{C}}+ð(\mathrm{I})]-\mathrm{P} \mid \mathrm{I})
$$

The equality of the two endpoints of this equation indicate that $\mathrm{P}=\mathrm{N}-\hat{\mathrm{C}}-ð(\mathrm{I})$; i.e., the investor pads his/her bid with a risk premium, which depends on the investor's information on cleanup costs.

Since information reduces the uncertainty of cleanup costs (i.e., increase the precision of the investor's cost estimate), it must reduce the investor's risk premium: $[\mathrm{d}((\mathrm{I}) / \mathrm{dI}]<0$. Conversely, ð(I) rises as I falls. Therefore, $\mathrm{P}$ falls as I degrades. To prove this point, fix $\mathrm{P}$ at $\mathrm{P}^{*}=\mathrm{N}-\hat{\mathrm{C}}$, the correct level when costs are certain. At this level $\mathrm{P}^{*}$, when $\mathrm{C}$ is uncertain, $ð(\mathrm{I})>0$ and $\mathrm{EU}<\overline{\mathrm{U}}$. Even though the latter condition holds, the theory can employ the assumption of second-order stochastic dominance and the definition of certainty equivalent to prove the inverse relationship between $ð(\mathrm{I})$ and I. Let $\mathrm{I}^{\prime}>\mathrm{I}^{\prime \prime}$, then the following relationships hold:

$$
\mathrm{U}\left(\mathrm{W}+\mathrm{N}-\left[\hat{\mathrm{C}}+ð\left(\mathrm{I}^{\prime}\right)\right]-\mathrm{P}^{*} \mid \mathrm{I}^{\prime}\right)=\mathrm{EU}\left(\mathrm{I}^{\prime}, \mathrm{P}^{*}\right)>\mathrm{EU}\left(\mathrm{I}^{\prime \prime}, \mathrm{P}^{*}\right)=\mathrm{U}\left(\mathrm{W}+\mathrm{N}-\left[\hat{\mathrm{C}}+ð\left(\mathrm{I}^{\prime \prime}\right)\right]-\mathrm{P}^{*} \mid \mathrm{I}^{\prime \prime}\right)
$$

The inner inequality of this equation follows directly from the assumption of second-order stochastic dominance. The left-hand and right-hand equalities follow directly from the definition of certain equivalent. The two endpoints of the equation reveal that $\partial\left(\mathrm{I}^{\prime}\right)<\partial\left(\mathrm{I}^{\prime \prime}\right)$, when $\mathrm{I}^{\prime}>\mathrm{I}^{\prime \prime}$, since no other parameters would permit the inequality. ${ }^{6}$ Therefore, $\partial(\mathrm{I})$ rises and $\mathrm{P}$ falls as information degrades. Finally, note that the investor must adjust its bid down from $\mathrm{P}^{*}=\mathrm{N}-\hat{\mathrm{C}}$ to $\mathrm{P}=\mathrm{N}-\hat{\mathrm{C}}-ð(\mathrm{I})$ in order to achieve its reservation utility, $\overline{\mathrm{U}}$.

As long as the investor is liable for cleanup costs, the investor's concern about cleanup costs, including any uncertainty, becomes the agency's concern. In order to attract investors, the agency

${ }^{6}$ This analysis is similar to previous research on the effect of risk on utility that began with Rothschild and Stiglitz (1970) and Rothschild and Stiglitz (1971). 
must accommodate the investors' expected cleanup costs and the risk premium stemming from the uncertain cleanup costs. This accommodation comes in the form of price reductions. Since the risk premium depends negatively on investor information about cleanup costs, this model predicts that the price paid by an investor falls (the price reduction rises) as information degrades, which represents the first testable hypothesis.

Hypothesis \# 1: The price reduction offered by a privatization agency to an investor rises as the investor's information on cleanup costs degrades.

Forthcoming empirical analysis will test for a systematic negative relationship between investor information and price reductions.

This model considers the scenario where the investor faces all of the liability and the government offers price reductions as compensation. The next model considers the scenario where the government may additionally choose to accept all of the liability, that is, completely indemnify the investor of private liability. This liability re-allocation mechanism may be quite attractive to the privatization agency since price discounts reduce sales revenues, including discounts linked to risk premiums.

\section{No Indemnification versus Complete Indemnification}

As a nice contrast to the previous model, consider the case where the privatization agency chooses between no indemnification, while offering a price discount, and complete indemnification, without any price discount. Given the first policy option, the investor faces all of the risk generated by uncertain cleanup costs and requires a risk premium in compensation. Given the second policy option, the investor faces none of the risk and requires no risk premium; however, the state bears the cleanup costs and other costs, such as administrative expenses. 
When the state considers indemnification as a policy option, its own-country welfare must include the costs associated with indemnification. Assume that the cleanup costs, $\mathrm{C}$, are independent of who pays them. In addition to cleanup costs, the state faces other expenses associated with indemnification, denoted as $\mathrm{K}$,

$$
\mathrm{K}=\text { indemnification expenses. }
$$

These expenses may include administrative expenses for operating any reimbursement program. They also may include costs claimed as past environmental contamination by the investor yet generated after privatization. This possibility is quite feasible since it may be very difficult, if not impossible, to separate past and current environmental contamination, which causes a moral hazard problem. ${ }^{7}$ Less obviously, indemnification may generate higher future cleanup costs by undermining the polluter pays principle and degrading deterrence of future contaminating activities. ${ }^{8}$

The agency chooses between zero and complete indemnification. Let $\mathrm{m}$ represent the choice to indemnify completely, $m=1$, or not to indemnify, $m=0: m \in\{0,1\}$. The agency's sales revenues net of state-born cleanup costs and indemnification expenses are denoted as $\mathrm{R}$, which depend on the indemnification choice:

$$
\mathrm{R}(\mathrm{m})=\mathrm{P}-\mathrm{mC}-\mathrm{mK}=\text { agency's net revenues. }
$$

In this case, the agency may face uncertain cleanup costs. The agency is assumed to be risk neutral and chooses to maximize the expected value of $\mathrm{R}$. When the state offers no indemnification and the investor faces the risk, the bid price is $\mathrm{P}(\mathrm{m}=0)=\mathrm{N}-\hat{\mathrm{C}}-ð(\mathrm{I})$ and the agency's net revenues are $\mathrm{R}(\mathrm{m}=0)=\mathrm{N}-\hat{\mathrm{C}}-ð(\mathrm{I})$. When the state offers complete indemnification and the investor faces no risk,

${ }^{7}$ See Boyd (1996) for an excellent discussion on this point.

${ }^{8}$ See Boyd (1996) for an excellent discussion on this point. 
the bid price is $\mathrm{P}(\mathrm{m}=1)=\mathrm{N}$ and the agency's expected net revenues are $\mathrm{R}(\mathrm{m}=1)=\mathrm{N}-\hat{\mathrm{C}}-\mathrm{K}$.

The state selects complete indemnification when $R(m=1)>R(m=0)$, which implies it selects $\mathrm{m}=1$ when $\mathrm{K}<\partial(\mathrm{I})$. As the investor's information on cleanup costs falls, the risk premium climbs; therefore, the likelihood of selecting indemnification rises. The contrary result follows when information improves. These results represent two hypotheses.

Hypothesis \# 2: As the investor's information on cleanup costs falls, the likelihood of the privatization agency offering indemnification rises.

Hypothesis \# 3: As information improves, the likelihood of offering a price discount rises. Forthcoming empirical analysis will test these hypotheses.

The next theoretical section generalizes the indemnification policy option and generates a fourth and related hypothesis.

\section{Degree of Partial Indemnification}

The final model generalizes the two previous models by including partial indemnification, while retaining the policy options of zero or full indemnification and a price discount.

In this general model, the privatization agency is able to offer any level of indemnification between none and full: $\mathrm{m} \in[0,1]$. As the level of indemnification rises, the cleanup costs born by the state, $\mathrm{mC}$, rise, as do the state's indemnification expenses, $\mathrm{mK}$. As the level of indemnification rises, the cleanup costs born by the investor, $(1-\mathrm{m}) \mathrm{C}$, fall, as does the expected level of cleanup costs, (1m) $\hat{\mathrm{C}}$, as shown in Figure 2. In response, the investor raises its bid price due to these lower expected costs.

Greater indemnification also generates second-order stochastic dominance, which lowers the risk premium, prompting the investor to raise its bid price. If $\mathrm{m}^{\prime}>\mathrm{m}^{\prime \prime}$, the distribution $\mathrm{f}\left(\mathrm{C} \mid \mathrm{I}, \mathrm{m}^{\prime}\right)$ 
second-order stochastically dominates the distribution $\mathrm{f}\left(\mathrm{C} \mid \mathrm{I}, \mathrm{m}^{\prime \prime}\right)$ because the first distribution more greatly reduces the scope of the investor's exposure to liability than does the second distribution. Similar to information, greater indemnification tightens the investor's cost estimate, in this case by reducing the spread between the minimum and maximum values of cleanup costs. As shown in Figure $2,\left(1-\mathrm{m}^{\prime}\right) \mathrm{C}_{\min }$ and $\left(1-\mathrm{m}^{\prime}\right) \mathrm{C}_{\max }$ are closer together than are $\left(1-\mathrm{m}^{\prime \prime}\right) \mathrm{C}_{\min }$ and $\left(1-\mathrm{m}^{\prime \prime}\right) \mathrm{C}_{\max }$. Unlike information, indemnification alters the expected value of cleanup costs.

Of course, second-order dominance holds even after adjusting for the difference in expected cleanup costs. The following equation captures the necessary adjustment:

$$
\mathrm{E}\left[\left(1-\mathrm{m}^{\prime}\right) \mathrm{C}+\mathrm{z} \mid \mathrm{I}, \mathrm{m}^{\prime}\right]=\mathrm{E}\left[\left(1-\mathrm{m}^{\prime \prime}\right) \mathrm{C} \mid \mathrm{I}, \mathrm{m}^{\prime \prime}\right],
$$

where $\mathrm{z}$ represents the shift parameter to preserve the means between the two distributions associated with indemnification levels $\mathrm{m}^{\prime}$ and $\mathrm{m}^{\prime \prime}$. Given this adjustment, second-order stochastic dominance implies the following relationship between the two levels of expected utility associated with indemnification levels $\mathrm{m}^{\prime}$ and $\mathrm{m}^{\prime \prime}$ :

$$
\int_{C} U\left(W+N-\left[\left(1-m^{\prime}\right) C+z\right]-P\right) f\left(C \mid I, m^{\prime}\right) d C>\int_{C} U\left(W+N-\left[\left(1-m^{\prime \prime}\right) C\right]-P\right) f\left(C \mid I, m^{\prime \prime}\right) d C,
$$

when $\mathrm{m}^{\prime}>\mathrm{m}^{\prime \prime}$. This mean-preserving spread does not alter the level of expected costs; instead, it affects only the riskiness associated with the two distributions. ${ }^{9}$

Therefore, this constructed second-order stochastic dominance affects only the investor's risk

${ }^{9}$ A simple example illustrates the mean-preserving adjustment and residual second-order stochastic dominance. Assume that cleanup costs are uniformly distributed over the interval $[100,1000]$. Consider two levels of indemnification: $\mathrm{m}^{\prime}=50 \%$ and $\mathrm{m}^{\prime \prime}=25 \%$. Before adjustment, the 50\%-indemnification policy generates an expected level of 275 and a post-indemnification interval of $[50,500]$ and the $25 \%$-indemnification policy generates an expected level of 412.5 and a post-indemnification interval of [75,750]. The shift parameter necessary to preserve the means between the two distributions is 137.5. After adjustment, the 50\%indemnification policy generates a post-indemnification interval of [187.5, 637.5], which obviously secondorder stochastically dominates the $25 \%$-indemnification interval of $[75,750]$. 
premium. As with information, greater indemnification reduces the investor's risk premium, $\partial(\mathrm{I}, \mathrm{m})$ : $(\partial ð / \partial \mathrm{m})<0$. Moreover, I reasonably assume that indemnification is less productive at reducing risk as the level rises: $\left(\partial^{2} \partial / \partial^{2} \mathrm{~m}\right)>0$; i.e., $\mathrm{m}$ reduces $ð(\mathrm{I}, \mathrm{m})$ at a declining rate..$^{10}$ Moreover, I assume that the level of indemnification and investor's information on cleanup costs act as substitutes for reducing the risk premium:

$$
\left[\partial^{2} \partial /(\partial \mathrm{m} \partial \mathrm{I})\right]>0 .
$$

In other words, indemnification becomes less meaningful for reducing risk as the investor becomes better informed about the cleanup costs. ${ }^{11,12}$

The investor's bid price is the following:

$$
\mathrm{P}=\mathrm{N}-(1-\mathrm{m}) \hat{\mathrm{C}}-ð(\mathrm{I}, \mathrm{m}) \text {. }
$$

Greater indemnification reduces the expected level of cleanup costs, which is reflected in $(1-\mathrm{m}) \hat{\mathrm{C}}$, and lowers the riskiness of uncertain costs (while adjusting for lower expected costs), which is reflected in $ð(\mathrm{I}, \mathrm{m})$. The agency's expected net revenues are the following:

$$
\mathrm{R}(\mathrm{m})=\mathrm{P}-\mathrm{m} \hat{\mathrm{C}}-\mathrm{mK} \text {. }
$$

Substituting P into $\mathrm{R}(\mathrm{m})$,

$$
\begin{aligned}
\mathrm{R}(\mathrm{m}) & =\mathrm{N}-(1-\mathrm{m}) \hat{\mathrm{C}}-ð(\mathrm{I}, \mathrm{m})-\mathrm{m} \hat{\mathrm{C}}-\mathrm{mK} \\
& =\mathrm{N}-\hat{\mathrm{C}}-ð(\mathrm{I}, \mathrm{m})-\mathrm{mK} .
\end{aligned}
$$

${ }^{10}$ This assumption places restrictions on the utility function and permits the existence of an optimal level of indemnification.

11 This assumption also places restrictions on the utility function.

12 Bluffstone and Panayotou (1998) examine the privatization agency's choice over the level of indemnification, while implicitly considering an investor's risk premium. Yet, their formulation does not reveal this relationship in a setting similar to this paper's setting. 
Maximizing expected net revenues with respect to the level of $m$ shows that the agency should set the level of $\mathrm{m}$ so that the following relationship holds:

$$
-[\partial ð(\mathrm{I}, \mathrm{m}) / \partial \mathrm{m}]=\mathrm{K} .
$$

Let $\mathrm{m}^{*}$ denote this maximizing level for $\mathrm{m}$.

Since the level of indemnification and investor's information about cleanup costs are substitutes, $\mathrm{m}^{*}$ is inversely related to the level of I. This result represents the fourth testable hypothesis.

Hypothesis \# 4: As the investor becomes better informed about cleanup costs, the privatization agency lowers the level of indemnification.

Forthcoming empirical analysis will test this hypothesis.

Lastly, this general model formulation includes previous results as testable hypotheses. At high levels of information, the state may optimally choose to offer no indemnification:

$$
-[\partial \partial(\mathrm{I}, \mathrm{m}) / \partial \mathrm{m}] \leq \mathrm{K} \text { at } \mathrm{m}=0 .
$$

At low levels of information, the agency may optimally choose to offer full indemnification:

$$
\text { - }[\partial ð(\mathrm{I}, \mathrm{m}) / \partial \mathrm{m}] \geq \mathrm{K} \text { at } \mathrm{m}=1 \text {. }
$$

\section{Empirical Analysis of Testable Hypotheses}

\subsection{Summary of Hypotheses}

In sum, the series of three models generates four testable hypotheses. First, when the state offers only price discounts without indemnification, the degree of price discount is inversely related to the amount of information known by the investor. Second (and third), when the state is deciding between zero and full indemnification, it is more likely to offer zero (full) indemnification as the amount of information rises (falls). Fourth, when the state is selecting any level of indemnification 
(including zero, partial, and full), it raises the level of indemnification as the investor's information falls. The following section proposes how to test empirically these hypotheses.

\subsection{Selection of Czech Republic as Research Site}

To test the above hypotheses, I propose to examine decisions made by the Czech Ministry of Privatization and its successor, the Czech Ministry of Finance. Although many countries in Central and Eastern Europe have responded to investors' concerns over past environmental contamination with various liability re-allocation mechanisms, the Czech Republic serves as the best case study for empirical analysis for two unique reasons. First, the Czech Republic has compiled meaningful data on environmental liabilities because it has re-allocated liability in a systematic manner; other countries have responded to investors' concerns in an ad hoc manner (Goldenman, 1995). Second and more important, the Czech government has offered liability re-allocation, in this case reimbursement for cleanup costs, to both foreign and domestic investors (Goldenman, 1995). Other national governments have offered liability re-allocation only to foreign investors. Such evidence certainly supports the hypotheses since foreigners would most likely represent the least-informed type of investor. Yet, the Czech data allows even stronger evidence to be offered.

\subsection{Privatization, Past Environmental Contamination, and Reimbursement in Czech Republic}

Government responses to investors' concerns about liability for environmental contamination at formerly state-owned enterprises have varied over time in the Czech Republic. (The appendix provides details on the clarification of liabilities.) Prior to March 1993, the Czech government negotiated responsibility for environmental liabilities on a case-by-case basis. It offered price discounts and limited indemnification to certain investors on an ad hoc basis. Beginning in March 1993, the Czech government started to address environmental liabilities systematically. Government 
Resolution No. 123/1993 established a system for re-allocating liability. First, it defines past environmental contamination to include only on-site environmental contamination: soil contamination, groundwater contamination, and hazardous waste dumps. Second, it prohibits price reductions on the basis of environmental cleanup costs. Third, it authorizes the National Property Fund (part of the Ministry of Finance) to reimburse investors for cleanup costs by negotiating individual contracts with new owners. (The appendix provides greater details on this fairly complex process.) Reimbursement of cleanup costs is limited to $100 \%$ of the purchase price or the value of the capital stock of a joint stock company; any costs beyond this limit remain the responsibility of the new owner. Otherwise, the National Property Fund has complete discretion about entering into environmental agreements with new owners. It is neither obliged to offer any assistance nor to offer complete assistance if it offers any. This discretion allows the forthcoming empirical analysis to test the theoreticallygenerated hypotheses.

\section{Summary}

In sum, this paper examines the link between an investor's information on the extent of past environmental contamination (and its related cleanup costs) and government efforts to placate an investor's concerns over liability for this contamination. These efforts re-allocate liability using legal mechanisms such as price discounts and indemnification. From this link, the theoretical section of this paper generates four hypotheses, which the empirical section of this paper proposes to test with forthcoming empirical analysis using data on liability re-allocation decisions in the Czech Republic. 


\begin{abstract}
APPENDIX
To understand fully the role of environmental liabilities, this appendix describes the Czech privatization process, which began in 1990. The first efforts focused on small enterprises, which did not involve environmental liabilities since this privatization did not transfer any types of liabilities to new owners. Restitution also began in 1990. As with small enterprises, it apparently does not transfer environmental liabilities to new owners (Kružíková and Drobnik, 1993). In 1991, the Czech government began to privatize medium and large enterprises. These transfers were concentrated in two waves of mass privatization involving mostly voucher privatization. Privatization of medium and large enterprises definitely involved environmental liabilities.

Although Czech laws do not establish a specific obligation to remediate past environmental contamination, they do establish general obligations to remediate contamination. Several environmental laws contain provisions addressing the obligation to remediate environmental contamination when required by an environmental authority (Goldenman, 1995). These environmental laws concern on-site and off-site environmental contamination. Other laws speak to other types of liabilities. Under Czech labor laws, a firm is liable for employees' injuries or illnesses sustained during their employment if the damage was caused by a violation of some legal obligation (Goldenman, 1995). Under the Czech civil code, companies are responsible for damages caused to third parties if the harmful activity violated a Czech law before January 1, 1992; after this date, the firm is liable for all damages regardless of the presence or absence of violations (Kružíková and Drobnik, 1993).
\end{abstract}

The 1991 Large-Scale Privatization Act clearly states that the new owner of a privatized enterprise acquires all assets and liabilities. A later amendment explicitly noted environmental 
liabilities. To clarify these liabilities, a 1992 amendment to the original act requires that all privatization projects submitted after February 29, 1992, must include an environmental audit which assesses the environmental liabilities of the specific enterprise, in addition to providing a record of previous violations and documenting the degree of noncompliance with current environmental regulations. Later in May 1992, the Czech Ministry of Privatization and the Czech Ministry of Environment jointly issued "Guidelines for Environmental Assessment", which provide directions for assessment of on-site contamination - with a focus on soil and groundwater contamination.

This appendix also describes the reimbursement process at the National Property Fund. In order to receive reimbursement from the National Property Fund, the following procedures must be followed. First, the new owner must perform an environmental audit and obtain approval of that audit from the Ministry of Environment (Goldenman, 1995). After receiving this approval, the new owner may apply for reimbursement through an environmental agreement with the National Property Fund, which forwards the application to the Ministry of Environment and the Ministry of Finance. If these ministries agree that a reimbursement contract is worthwhile, the National Property Fund negotiates a contact with the new owner. After signing the agreement with the National Property Fund, the new owner must provide a risk assessment in compliance with Government Resolution No. 393/1994. Based on this risk assessment, the Czech Inspection of the Environment (part of the Ministry of Environment) determines whether or not remediation is necessary; if necessary, it imposes against the new owner a remediation order, which identifies the acceptable standards to be met in the remediation work. After receiving this administrative order, the new owner must complete a tender process for a remediation program that obtains the required environmental standards. Finally, the environmental contract for reimbursement must be approved by the Czech government when it 
decides on the specific privatization project (Goldenman, 1995).

Several enterprises and investors have participated in this process. By May 1996, Czech investors had performed over 4,000 environmental audits, implemented over 200 risk assessments, and received over 104 environmental agreements, valued at CZK 102 billion ( $\$ 3.75$ billion). 


\section{REFERENCES}

Bluffstone, Randall and Theodore Panayotou (1998), "Environmental Liability and Privatization in Central and Eastern Europe: Toward an Optimal Policy,” Harvard Institute for International Development (HIID) working paper, Harvard University.

Boyd, James (1996), "Environmental Liability Reform and Privatization in Central and Eastern Europe," European Journal of Law and Economics, v. 3, n. 1, pg. 39-60.

The Economist (1993), “Environmental Liabilities: Dirty Legacy,” September 18, 1993.

Kružíková, Eva and Jaroslav Drobnik (1993), "Privatization and Liability for the Past Environmental Damages," mimeo, Institute for Environmental Policy, Prague, Czech Republic.

Goldenman, Gretta (1995), “Central European Approaches to Concerns About Environmental Liability During and After Privatization,” International Environment Reporter, September 6, 1995, pg. 696-701.

Rothschild, M. and Joseph Stiglitz (1970), “Increasing Risk I: A Definition,” Journal of Economic Theory, v. 2, pg. 225-243.

Rothschild, M. and Joseph Stiglitz (1971), "Increasing Risk II: Its Economic Consequences," Journal of Economic Theory, v. 3, pg. 66-84.

Thomas, Randall (1994), "The Impact of Environmental Liability on Privatization in Central and Eastern Europe: A Case Study of Poland," University of California Davis Law Review, v. 28, pg. $165-217$.

World Bank / OECD (1992), Corporate Survey on Western Direct Investment and Environmental Issues in Central and Eastern Europe, Washington, DC: World Bank. 
Figure 1

Effect of Investor's Information on Distribution of Cleanup Costs

Probability

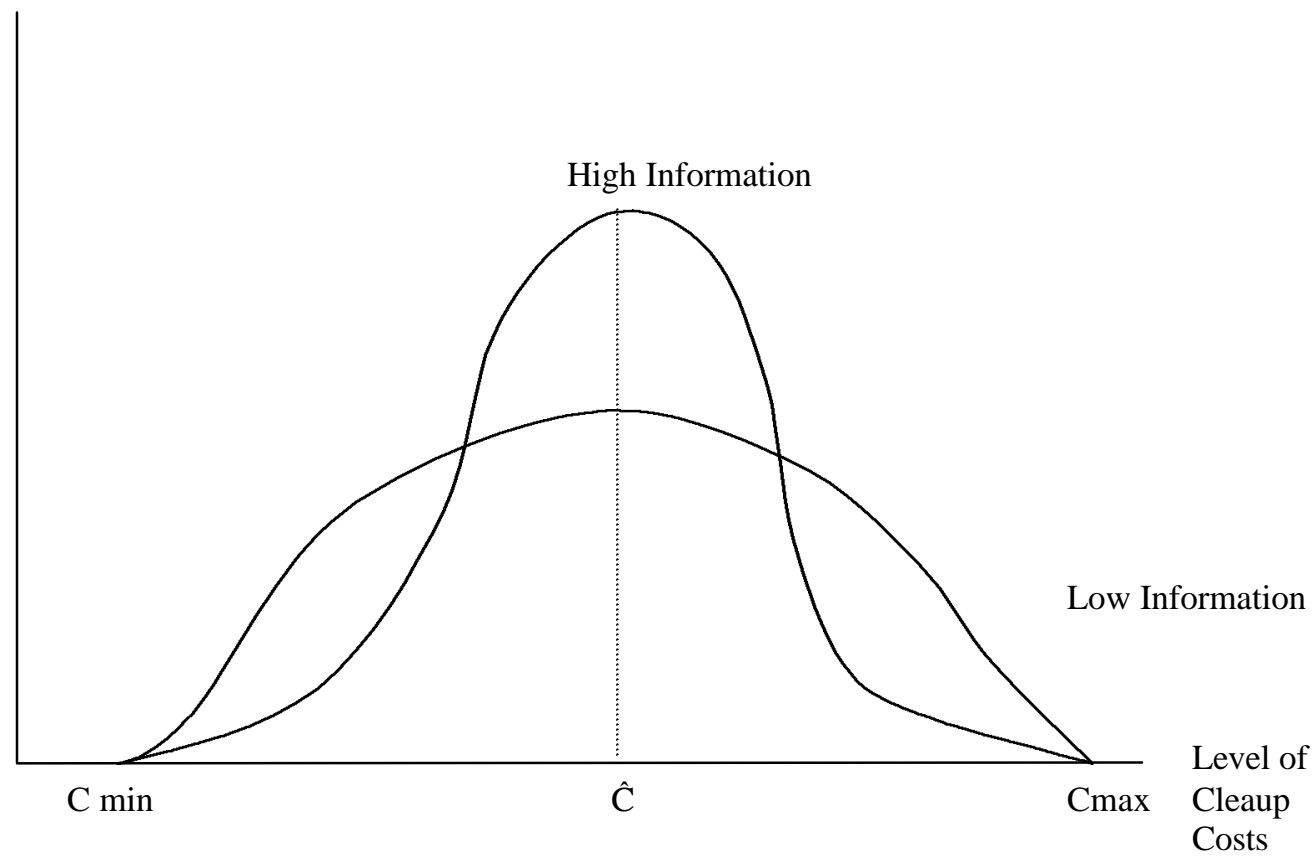


Figure 2

\section{Effect of Indemnification on Distribution of Cleanup Costs}

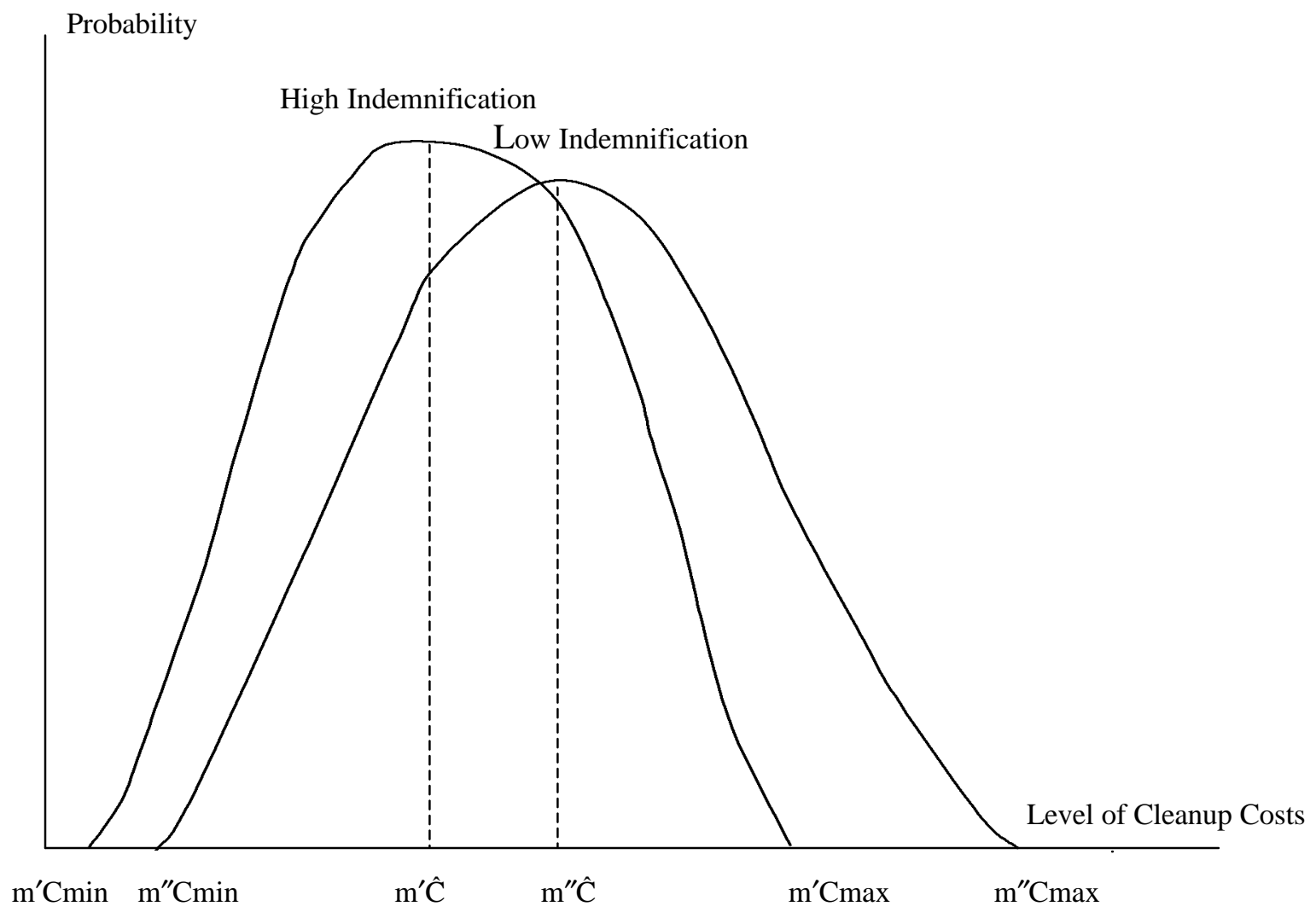

